\title{
Beyond all Utterance: Reflections on the making of the films Memoirs of a Plague and Locusts: Creatures of the flood
}

\author{
Robert Nugent
}

All visible objects, man, are but as pasteboard masks.

— Herman Melville, Moby Dick ${ }^{1}$

This paper reflects on the making of two very different films by the author. Both films were on the same subject: our relationship with locusts. One film, Memoirs of a Plague, was a personal inquiry, informed by an ethnographic filmmaking approach. The other film, Locusts: Creatures of the flood, was created from the same source material as Memoirs of a Plague, but was made for an international cable television channel, according to the demand for a magazinestyle documentary. ${ }^{2}$

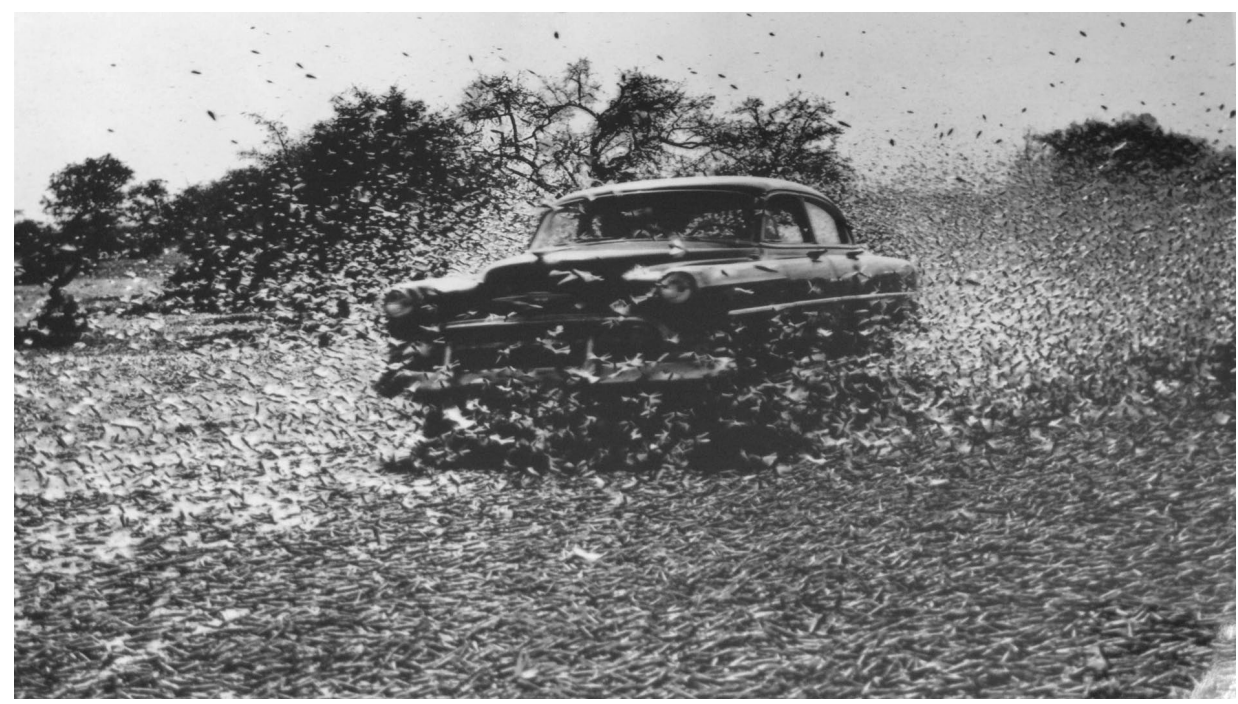

Figure 1 Locust invasion on the road to Tiznit, French Morocco, Nov 1954

Source: Food and Agriculture Organisation (photo by Studies du Souissi, Rabat)

1 Melville, H. 1992 [1851], Moby Dick, Penguin Books, New York, p. 178.

2 Nugent, R. 2011, Memoirs of a Plague, Looking Glass Pictures, Sydney; Nugent, R. 2011, Locusts: Creatures of the flood, National Geographic. Both films were produced by Mitzi Goldman and Robert Nugent, Looking Glass Pictures, Sydney, and Viafilm, Canberra. 


\section{Background}

In 2008 I started making an independent film called Memoirs of a Plague. The numerous journeys I undertook to make the film over the next three years took the form of a personal and idiosyncratic inquiry into locust control around the world. My initial thesis was that our reactions to the natural phenomenon of locusts may arise from long-held prejudices and myths, rather than the reality of the threat that they pose. The film was based on found situations where individuals and governments were confronting what they perceived to be a locust menace. The bulk of the funding for Memoirs of a Plague came from Screen Australia's Innovation Program.

In the course of my filming of Memoirs of a Plague, National Geographic became interested in the project and commissioned the making of a television version. This was to be a bespoke film, which came to be called Locusts: Creatures of the flood. It was to be made from the same source material as Memoirs of a Plague. ${ }^{3}$

While the cinematography in both films was inspired by National Geographic's leadership in natural history filmmaking, the film that I was to make for them would have to conform to a style to which their audiences had become accustomed. A commissioning editor explicitly told me that the form of Memoirs of a Plague was completely unsuitable for the audience to which they marketed their films; however, there was no manual to explain this difference or the process by which Memoirs of a Plague needed to be reconfigured for television.

The stark difference in logic instantiated in Memoirs of a Plague and Locusts: Creatures of the Flood, and the approaches to filmmaking they stand for, is revealed when we reflect upon the way the two films were constructed. In what follows, I will compare and discuss some aspects of the making of the two films. I hope this discussion may contribute to critical understandings of how different the process of filmmaking can be when confronting the same subject. My own filmmaking practice has been strongly influenced by ethnographic films, modelled on the approach of filmmakers such as Jean Rouch, David MacDougall and Lucien Castaing-Taylor. In this spirit, I approached the filming of Memoirs of a Plague as an open-ended inquiry. I attempted to incorporate a sense of the process of filming as well as acknowledging my own relationship to the subject.

In the case of Creatures of the Flood, the approach was to be very different. I was aware that this film was to be created as content for a market dominated by television-style documentary films, and where it is expected such films will provide an audience with both questions and answers.

\footnotetext{
3 Memoirs of a Plague ran to 77 minutes in length. Creatures of a Flood was contractually required to be exactly 52 minutes long, which is the specified length of a television program hour.
} 


\section{Filmic Beginnings}

Moby Dick inhabited my mind in 2007. I was nearing the end of three years of work on my film End of the Rainbow. ${ }^{4}$ Reading about whales and the ocean was one way of escaping the intensity of finishing the film. I was fascinated by Ahab's obsessive pursuit of Moby Dick. The white whale speaks for many hounded creatures. This association led me to develop an idea I already had for a film on locusts - a subject that had interested me since my employment as a field officer with the Australian Plague Locust Commission when I first left university. I chose to ignore Herman Melville's advice. He cautioned against casting a character such as a locust: 'To produce a mighty book, you must choose a mighty theme. No great and enduring volume can ever be written on the flea, though many there be who have tried it.'

In 2008 I began a cinematic investigation into the phenomenon of locusts in our imaginations. I set myself the task of not using an expositional voice-over, which is a common device in the filmmaker's toolkit. I wanted to rely on the power of the cinematic image of the locusts, and their hunters, as the primary means to convey the story as I found it through the lens of a camera.

In adopting this approach, I was also influenced by the way ethnographic filmmakers may use cinema to explore a subject that is initially unfamiliar to them. From my own experience, this means crossing a cultural threshold, with a camera in hand. I find you must put aside, as much as this is possible, any sense of a predetermined dramatic premise. If there was drama in the human conflict with locusts, I set myself the task of discerning it through what I could record with the camera. As ethnographic filmmakers have done before me, I was leaving my own world behind and allowing myself to be confronted with the immensity of the present moment. When you initially cross this threshold anything and everything can be of significance to your recording device - which of course you are always aware you will take back to your own world. At the beginning of such a crossing I find my camera could just as well be mounted on NASA's Mars Explorer or the barrel of a tank (as it was in a film that I made when I spent a month with the Australian Army in Iraq in 2006 as a war artist). ${ }^{6}$

After entering the world of the locust hunters, I became familiar with the people I met and their quest to find and kill locusts. As it was not my intention to make a natural history film, their personal motivations and intentions were of more significance to me than the locusts they hunted. The relationship that

\footnotetext{
4 Nugent, R. 2007, End of the Rainbow, Looking Glass Pictures, Sydney. End of the Rainbow was set in the goldfields of Guinea in West Africa with a griot narrator. The film was a co-production between Arte in France, ITVS in the United States and SBS in Australia. It was my first feature-length film.

5 Melville, Moby Dick, p. 497.

6 Nugent, R. 2008, No Dramas: Recordings from Iraq, Australian War Memorial, Canberra.
} 
developed between myself, as the filmmaker, and my subjects became crucial to the film, and for me this is one of the hallmarks of ethnographic filmmaking and of ethnographic inquiry.

I had been inspired by the relationship Jean Rouch had with his subjects when he made Jaguar, which had informed my earlier film End of the Rainbow. ${ }^{7}$ There are many examples of cross-cultural relationships that develop between the filmmakers and their subjects in ethnographic films (for example, Room 11, Ethiopian Hotel ${ }^{8}$ and Koriam's Law ${ }^{9}$. I believe, however, there is no one particular method or approach that distinguishes an 'ethnographic film', though the question is often asked.

In setting out to make the film on locusts in the way that I was proceeding, I was encouraged by the theoretical writings of Bill Nichols, who argued that ethnographic filmmakers 'in their meditations on scientific method and visual communication, have done the most provocative experimentation' ${ }^{10}$

In my pocket, however, I always carried Robert Bresson's Notes on the Cinematographer, which ostensibly has nothing at all to do with ethnographic film. It is more a collection of personal responses and aphorisms that Bresson compiled during his filmmaking practice. In my mind, he had formulated a response to Melville's entreaty to never make a film on a flea (or a locust in my case) when he said '[a] small subject can provide the pretext for many profound combinations. [But] avoid subjects that are too vast and remote, in which nothing warns you are going astray. Or else take from them only what can be mingled with your life and belongs to your experience.'11 For me, this advice fits well with the rubric of ethnographic film.

Béla Balázs writes, 'The realities of nature are given their deepest meaning for man if presented as a social experience', ${ }^{12}$ so an inquiry informed by ethnographic research approaches and the entreaty of André Bazin to recognise 'cinema as language ${ }^{13}$ seemed an eminently suitable way of investigating responses to such a protean being as the locust.

This investigation began in January 2008 when I travelled from Australia to Ethiopia. The outcome was far from certain. My trip, however, was not a

7 Rouch, J. 1958, Jaguar, Documentary Educational Resources, Watertown, Mass.

8 Kawase, I. 2006, Room 11, and Ethiopian Hotel, Kyoto University, Japan.

9 Kildea, G. and Simon, A. 2006, Koriam's Law, Ronin Films, Canberra.

10 Nichols, W. 1991, Representing Reality: Issues and concepts in documentary, Indiana University Press, Bloomington.

11 Bresson, R. 1975, Notes on the Cinematographer, P. Bregne and G. Bennett (eds), Green Integer Books, California, p. 50.

12 Balázs, B. 1952, Theory of the Film, E. Bone (trans.), Dennis Dobson Limited, London, p. 163.

13 Bazin, A. and Gray, H. 1960, 'The ontology of the photographic image', Film Quarterly, vol. 13, no. 4 (Summer), pp. 4-9. 
completely speculative exercise. Much time and scientific resources are devoted to forecasting the occurrence of locusts. The web site of the United Nation's Food and Agriculture Organisation (FAO) reported that they were likely to be in the south of the country. ${ }^{14}$ The locusts had apparently flown in from the Ogaden, which was an area off limits to locust-monitoring efforts because of the war in Somalia. In Addis Ababa, I hired a car and driver and spent several days following news of the locusts.

Ethiopia lies across Africa's huge Rift Valley. It is breathtakingly beautiful. My eyes, accustomed to the low-slung landscapes of Australia, found the country hard to read. Such is the scale of the Rift Valley that you can drive for hours towards a volcano and never seem nearer. I followed stories of locusts to the Konso area of southern Ethiopia.

When I arrived there, miraculously it seemed, before me was a tableau of human interaction with locusts. I had not expected to be quite so quickly confronted with a particular dilemma of exploratory filmmaking. How to maintain a critical distance from your subject? Usually I find this is done by building experience within the world you have entered, and getting to know the people, keeping notes and watching your daily 'rushes', ${ }^{15}$ which allows the filmmaker time to build up a sense of how the images are 'working'. It helps to build a director's sense of what the story is in cinematic terms. In southern Ethiopia I had no time for this. Filmmaking, ethnographic or not, is primarily a very physical activity, which requires stamina and practice, mixed with just such moments of serendipity. I needed to physically immerse myself in a rapidly unfolding and ephemeral event. The sudden appearance of the locusts understandably panicked the villagers. Though they had never seen them before, they believed that their livelihoods were threatened. Pesticides were deployed. The Desert Locust Control Organisation for East Africa sent a sixty-year-old Dehaviland Beaver spray aircraft from Nairobi, flown by the charismatic Captain Aralleh, who became my Captain Ahab, as I was swept into his quest to find and kill the swarm.

The scene that I encountered in southern Ethiopia shows the fear, confusion and chaos that locusts cause. The film of their arrival is suitably dramatic and conforms to a popular part of the locust narrative. The plague had arrived out of nowhere. Villagers of all ages were running wildly about, cracking whips, beating bushes, banging drums and lighting fires to scare the locusts. ${ }^{16}$

14 http://www.fao.org/ag/locusts/en/activ/DLIS/

15 Rushes is the term now commonly used to describe 'raw' or unedited footage. It derives from the predigital practice in fiction filmmaking of quickly processing each day's footage for viewing by the director. 16 To view this scene, see the end sequence of Memoirs of a Plague via the ANU E Press website at http:// epress.anu.edu.au/titles/humanities-research-journal-series/humanities-research-vol-xviii-no-1-2012 


\section{The Character of the Locust}

In the locust there exists a character where science, powerful inbuilt narratives and norms of representation intersect in a singular way. Locusts can stand for many different things, and their narrative comes preloaded with metaphors. They have the power to elicit strong emotional responses. Pre-colonial shifting agricultural communities and nomadic tribes in Africa often regarded them as a sign of plenty. ${ }^{17}$ To societies built around sedentary agriculture and established land-tenure systems, the way that locusts seem to strike indiscriminately automatically casts them as pestilence.

Our war with locusts has been continuing for millennia. The battles, though dramatic, often lead to no clear victory. They take place today on the margins of the food bowls of Africa, Asia and the Middle East, in societies in which locusts are creatures of mythology as well as entomology, a source of food as well as a source of fear. When in plague, locusts evoke the threat of uncontrollable and malevolent nature, and may even be seen as a symptom of social and moral disintegration. Locust plagues are often associated with regions of conflict, and connections between locusts and war are manifold. While the science, chemicals and techniques have evolved, locust killing has changed little since the advent of the aerial application of insecticides, which was an idea borrowed from the use of aircraft to drop bombs. Today the most commonly applied chemical used in locust control has been derived from nerve gas used to kill humans during wartime. ${ }^{18}$ Even the occurrence of locusts frequently coincides with regions made inaccessible because of security concerns or warfare, as outlined by Brader and colleagues in their 2006 report to the FAO. ${ }^{19}$

Locusts have a political dimension. As they are migratory creatures, they can flagrantly cross borders, which potentially can create disputes between neighbours. Individuals feel powerless in the face of invasion and so locusts seem to have been universally adopted as an insect for which the state bears primary responsibility. There is even a character set in the Chinese alphabet that designates the locust as belonging to the Emperor.

17 Achebe, C. 1994 [1959], Things Fall Apart, Random House, New York. In this novel, the Igbo tribe saw locusts as a cause for celebration because they are a source of food.

18 These are the organophosphate class of chemicals, which kill by disrupting the signals between nerve synapses. The Germans first developed them as nerve gas during World War II.

19 Brader, L. 2006, 'Towards a more effective response to desert locusts and their impacts on food security, livelihoods and poverty', Multilateral Evaluation of the 2003-05 Desert Locust Campaign, Food and Agriculture Organisation of the United Nations, Rome, p. 40. 


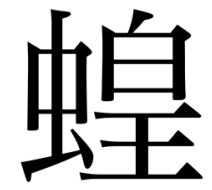

\section{Figure 2 Chinese character for the Emperor's insect: the locust}

In response, large, publicly funded state, national and international organisations dedicated to locust forecasting and control have been established around the world.

One of the main distinguishing characteristics of a locust, as well as a prodigious ability to migrate, is its capacity to exist in two morphologically distinct phases. The desert locust, which is the creature referenced in the Bible and the one that had arrived unexpectedly in southern Ethiopia in January 2008, normally exists as a large, nimble, solitary, green grasshopper. ${ }^{20}$ With the right combination of rainfall and density of the insects, hormonal changes can be triggered in the animal. While this process is not completely understood, they then transform into something very different from a humble grasshopper. Over the course of one or two generations they may first turn pink and then become a bright-yellow, swarming creature. This usually occurs out of sight, in remote desert regions. The fact that one creature can manifest itself in a form that is morphologically distinct from its parents was discovered early in the past century by the father of locust science, Sir Boris Uvarov. ${ }^{21}$ He had found the source of the biblical plague. Until this revelation, locusts had always seemed to appear out of nowhere. ${ }^{22}$

Though it was the first time locusts had appeared in southern Ethiopia in living memory, the villagers' consternation was understandable. They may not have met locusts before but they knew their reputation. I found this to be a characteristic of how our memories of locusts are formed. Because as individuals we may encounter them so infrequently and unexpectedly, and the experience is so visually arresting, they tend to become a uniquely memorable event in our lives. They form an image in our minds that cannot be described in words alone. David MacDougall has described this as embodying 'the gap between sensory experience and knowledge' ${ }^{23}$

\footnotetext{
20 Locusts are grasshoppers and members of the taxonomic family Acrididae.

21 Uvarov, B. 1982 [1928], Grasshoppers and Locusts, Natural Resources Institute UK, London.

22 Locusts have gone on to become the world's most studied insect and acridology, the study of grasshoppers and locusts, is a sub-branch of entomology.

23 MacDougall, D. 2006, The Corporeal Image: Film, ethnography and the senses, Princeton University Press, Princeton, NJ, p. 44.
} 


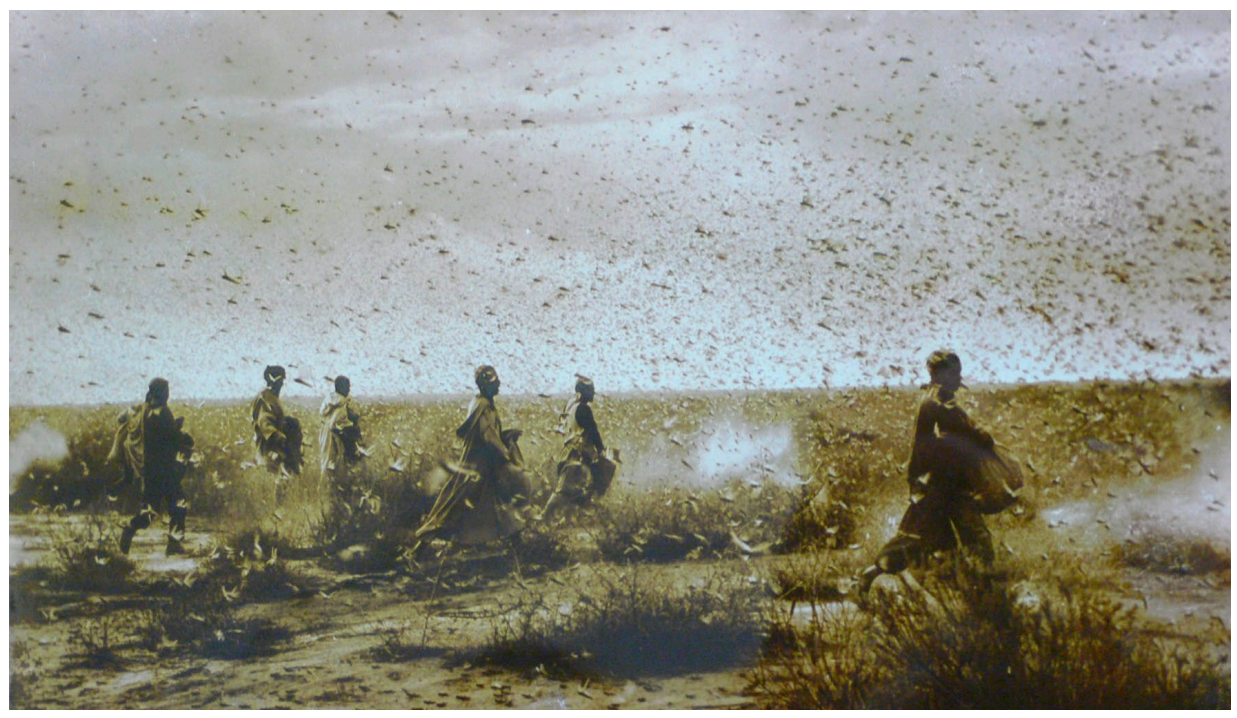

\section{Figure 3 Attacking an adult swarm with poison bait, French Morocco, Nov 1954}

Source: Food and Agriculture Organisation (photo by Studies du Souissi, Rabat)

Films about locusts form a prominent place in the genre of natural history documentaries, to the point where they could almost be regarded as a subgenre. ${ }^{24}$ The locust is firmly typecast as the antagonist in this drama-a role reinforced and amplified by the media whenever locusts are reported. In a 'locust film', or a media headline, they are generally introduced by way of a reference to one of the many apocalyptic allusions to them in the Bible. ${ }^{25}$ In a memorable scene from Terrence Malick's 1978 film, Days of Heaven, based on the story of Cain and Abel, hapless wheat farmers try to scare off a swarm of locusts using burning torches. In the process, they manage to set on fire and destroy the crop they are trying to save. ${ }^{26}$ In Australia, the notorious bushranger Ned Kelly made use of the reputation of the locust. He ends his famous 'Jerilderie Letter' with the warning that if his words are neglected, 'abide by the consequences, which shall be worse than...the grasshoppers in New South Wales'.$^{27}$

In contrast with their significance in our imaginations, a locust swarm is a surprisingly ephemeral and, in any one location, quite a rare event. Stephen Simpson, a pre-eminent locust scientist, provides the compelling, but unverified,

24 Examples include the classics: Gordan, D. 1956, The Ruthless One, Shell Film Unit, UK; and Hankinson, M. 1953, Teeth of the Wind, World Wide Pictures, London.

25 Although most documentaries about locusts do not quote Leviticus 11:22, which informs man that locusts are a good source of food.

26 Malick, T. 1978, Days of Heaven, Paramount Pictures, Los Angeles.

27 Kelly, E. 1879, The Jerilderie Letter, State Library of Victoria, Melbourne. 
statistic that one in ten people in the world has had their life affected by locusts; ${ }^{28}$ however, it would seem that for most of us the sight of them in plague proportions may only be a once-in-a-lifetime glimpse.

There are many claims made in the scientific literature of locusts causing substantial crop losses; however, the language used to describe this outcome is often framed by the word 'perceived' ${ }^{29}$ Conspicuously absent from the locust narrative is any published hard evidence that they alone cause widespread famine or even minor regional food-supply problems. ${ }^{30}$ During the three years that I worked as a field officer with the Australian Government's Plague Locust Commission, I pursued the insects over much of inland Australia and saw many swarms. I participated in the great plague of 1984 (in the literature, locust plagues, like other natural disasters, are always referred to by the year in which they occur) but I never witnessed the wide areas of barren fields they are supposed to leave in their wake. The many farmers and scientists whom I met always referred to their destructive capacity, though the reporting of damage caused by locusts was usually very subjective. One possible source of the attribution of major crop losses to locusts is the application of what appears to be self-evident logic. It is a part of locust lore that each insect will eat its own weight in food (it is presumed to be our food) every day; however, locusts don't always feed in this way throughout their life cycle, and they prefer certain foods over others. For instance, in the large desert locust plague that occurred in Pakistan in 1993, high-density swarms occupied thousands of square kilometres of the Thar Desert, which lies directly next to Pakistan's Indus River food basin, yet very few crops were attacked. I was employed there at the time as the United Nation's Food and Agriculture advisor and was present throughout the plague. Yet on witnessing those massive swarms of locusts, and knowing any one of them could contain a biomass equivalent to that of a sperm whale, I too have known the uncertainty that they cause. As Ishmael said of the ocean that Moby Dick swam through: 'It is the image of the ungraspable phantom of life; and this is the key to it all."31

Locusts, as characters in the film I was researching, were that ungraspable phantom: a state of mind. The subject I was investigating was not the locust itself, but our response to them. Their narrative was not the story of the 'evil other', but the story of our need to control uncertainty. In closely observing and

28 Bazazi, S., Buhl, J., Hale, J. J., Anstey, M. L., Sword, G. A., Simpson, S. J. and Couzin, I. D. 2008, 'Collective motion and cannibalism in locust migratory bands', Current Biology, vol. 18, no. 10, pp. 735-9.

29 Miers, H. and Thomson, A. 2002, Assessment of the Socio-Economic Impact of the Desert Locust and their Control, Oxford Policy Management.

30 Brader, 'Towards a more effective response to desert locusts'. Losses attributed to locusts often occur in the presence of compounding factors such as food insecurity caused by other causes, rural poverty, isolation, political expediency, exaggerated or misinformed reporting, lack of governance, social dislocation, warfare, and so on

31 Melville, Moby Dick, p. 5. 
filming people's interactions with locusts, wherever I could find them, I hoped I would be able to create a film that critiqued this need and, more broadly, our relationship with the natural world.

One way of doing this was to refrain from using a classic natural history expository voice-over during the macro-photography of the life cycle of the locust. In film language, extreme close-ups generally invite an audience to associate more strongly with the point of view of a character by drawing the viewer into their point of view. By not utilising a voice-over relaying scientific facts and explaining that the locust is the antagonist in the drama being portrayed, I hoped viewers may come to reassess their own ways of seeing and knowing a subject. By not casting the locust as an antagonist, I aimed to allow viewers a range of possible responses, including associating with the locust as a protagonist.

After Ethiopia, I made numerous trips over the next three years to film locustcontrol efforts in Egypt, Tanzania and Australia. As a locust swarm is not a prescribed event, the situations that I found myself filming were unique each time, and I chose to document them in that way.

\section{Memoirs of a Plague}

A range of stories appears in Memoirs of a Plague. Each explores different aspects of our relationship with locusts. The film uses cinematic devices such as associative editing, where the viewer is invited to make connections between scenes and interwoven storylines. Stories of love, fear and even boredom are assembled as a pastiche, in the way experiences may be jotted down in a travel diary. Farmers, officialdom and scientific researchers all make cameo appearances. They also appear as inherently incidental to the natural world that the locusts inhabit. The creatures are born, grow, migrate, reproduce and die, supremely indifferent to their effect on our imaginations and fears. The life cycle of the locust structures the film. It is presented in a conventional natural history film form, except that there is no voice-over explaining the images.

In contrast, my first-person voice-over narration threads through Memoirs of a Plague as a reflexive inner voice. This was constructed from notes that I kept while making the film, as I felt the need to frame images by reflecting on my own search for the 'plague'. The approach was influenced by, among others, the work of Lucien Castaing-Taylor and Ilisa Barbash. In filming Sweetgrass, Castaing-Taylor seeks to represent the flux of life with an ethnographic eye, propelled by an artistic sensibility. ${ }^{32}$ The way the camera lingers on subjects in Sweetgrass invites the audience to see along with the filmmaker. This subjective framing becomes the voice of Taylor-Castaing. The voice that I developed to place myself within my research ended up being a rhetorical device. If I never found the scourge of the plague, where does it exist except as a state of mind? Does our conditioning condemn us to always react in the same way? 


\section{View Opening Sequence from Memoirs of a Plague r $^{33}$}

Memoirs of a Plague starts off with the proposition that I had entered a world permanently at war with the uncontrollable forces of nature. Archival footage restates long-held views on locusts, followed by a scene that is in the style of a horror film. ${ }^{34}$ A mother is trapped in a car with her screaming children as a locust swarm engulfs them. She questions her fate by asking, 'Why now?' My voice casts her question in the broader context of all our lives. In the next scene, an unidentified person's arm is being tattooed with the image of a locust. The visceral nature of this procedure is conveyed by extreme close-up shots. I leave it up to the audience to reflect on the image of a locust forming on bloodied skin, and the decision to have it permanently placed there. My own voice reappears occasionally throughout the film as a querulous and infrequent inner reflection on my own subjective reactions - but it is uncertain and propositional.

After the title sequence of Memoirs of a Plague, I appear suddenly in a horsedrawn buggy next to two people. In the background there is an aeroplane that has run out of fuel. We are in a situation that none of us can control and we are heading for an unknown destination, surrounded by the cacophony of life.

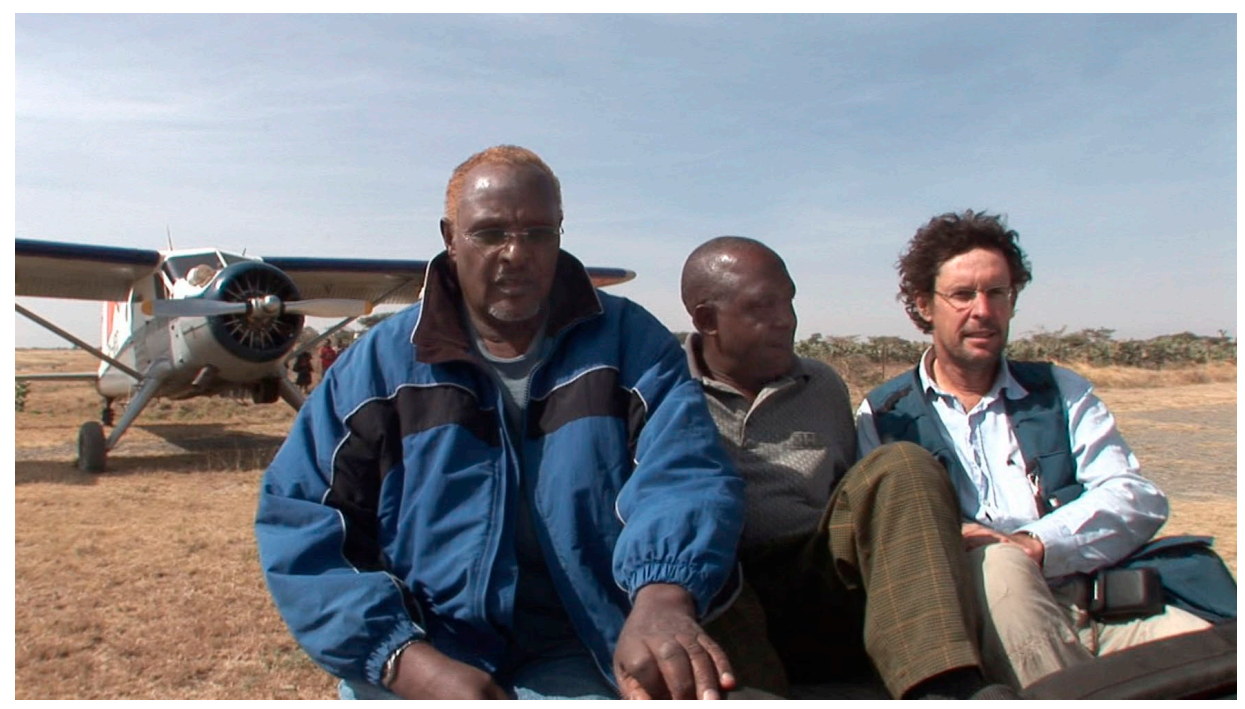

Figure 4 The author (right) in Ethiopia in February 2008, with two characters from Memoirs of a Plague: Captain Mohammed Arralleh (left) and Engineer Simon (centre)

Source: Still image taken from Memoirs of a Plague (2011)

\footnotetext{
33 View associated media files via the ANU E Press website at http://epress.anu.edu.au/titles/humanitiesresearch-journal-series/humanities-research-vol-xviii-no-1-2012

34 This was one of several cinematic tropes that Memoirs of a Plague employed that National Geographic requested not appear in Creatures of the Flood.
} 


\section{A Comparison with the Television Version, Creatures of the Flood}

The process of constructing Creatures of the Flood, and conforming it for television, involved re-editing Memoirs of a Plague to meet the needs of a major television distribution company. Finding out what these needs were was, in a practical sense, straightforward. We would send the commissioning editors rough cuts of the film that was to become Locusts: Creatures of the Flood and they would send us back a list of their requirements and suggestions for changes.

The first major requirement for Creatures of the Flood was for narration, which must be delivered in the third person via an unidentified voice. They wanted words to explain the images and sequences. So, in contrast with Memoirs of a Plague, Creatures of the Flood starts off with an anonymous voice-over, reiterating the relationship between man and locusts. This voice introduces the premise that locusts may not be the evil creatures we think they are. The voice also implicitly tells an audience that a narrator is going to lead them through the film they are about to watch.

\section{View Opening Sequence from Creatures of the Flood ${ }^{35}$}

In Memoirs of a Plague one of my aims was to raise questions about the genesis of our understanding of locusts. We develop our responses to the natural world very early in our lives. The scene from Memoirs of a Plague that takes place in a kindergarten in Coonamble in New South Wales shows children being instructed in the collective enterprise of finding and killing all locusts. It was a request that this scene not appear in Creatures of the Flood.

The locust scout, whom we meet in Memoirs of a Plague in a car in the Egyptian desert, is a Bedouin nomad from the Ababda tribe. The Ababda traditionally provided transport and guide services across the Eastern Arabian Desert, which runs along the western coastline of the Red Sea in Egypt. In the film $\mathrm{M}^{\prime} \mathrm{Hd}$ is fulfilling his traditional role of scout and guide for the Egyptian locust service scientists. I was interested in his relationship with the government officials. He seemed relegated to a defined role and excluded from the generation of a 'scientific understanding' of locusts. I wanted to focus on his way of viewing the desert as opposed to the way that the government officials and scientists come to understand locusts and the desert. The locust scout provides an alternative way of knowing locusts, one that is based on traditional knowledge and understandings of place and landscape. The scenes from Egypt were not required to appear in the television version because the character of the locust

35 View associated media files via the ANU E Press website at http://epress.anu.edu.au/titles/humanitiesresearch-journal-series/humanities-research-vol-xviii-no-1-2012 
scout, and the intentions of the scientists to find the locusts, would have had to be explained rather than observed. Apparently a television audience could not be expected to make such subtle connections on their own.

In Memoirs of a Plague, a vivisection scene follows from the ideas set up by the search for locusts in Egypt. The Ababda locust scout represented a relationship with nature vastly different from that of the scientists he was leading into it. In the lab it could be one of these same scientists whose gloved hand manipulates the locust. The use of extreme macro-photography amplifies its vulnerability and individuality. The scene invites the audience to empathise with the locust's plight. Again, the distribution company asked that this scene not appear, as it was deemed too graphic.

As they are cold blooded, locusts need to warm themselves in the sun. When they are warm enough they are very skittish creatures and difficult to film. While we have little idea how they perceive the world, as the voice of the scientist tells us, they are certainly very sensitive to movement. The slightest hint of a looming object will cause them to instantaneously vanish from the screen. But if locusts are cooled they become compliant actors. To film the diorama used at the end of Memoirs of a Plague, the locust that appears in the shot had been captured in a net and placed in an ice-filled box until it was too cool to hop away. Before it could warm up, I reached in and repositioned it, so that it could be filmed sitting on the rock in profile. When the film was edited I decided to show the shot of my hand moving the locust to signify my manipulating presence. Is it the hand of God re-establishing the natural order, or the hand of man, who can never stop controlling events? The shot had to be cut from Creatures of the Flood because it was once again too open to interpretation.

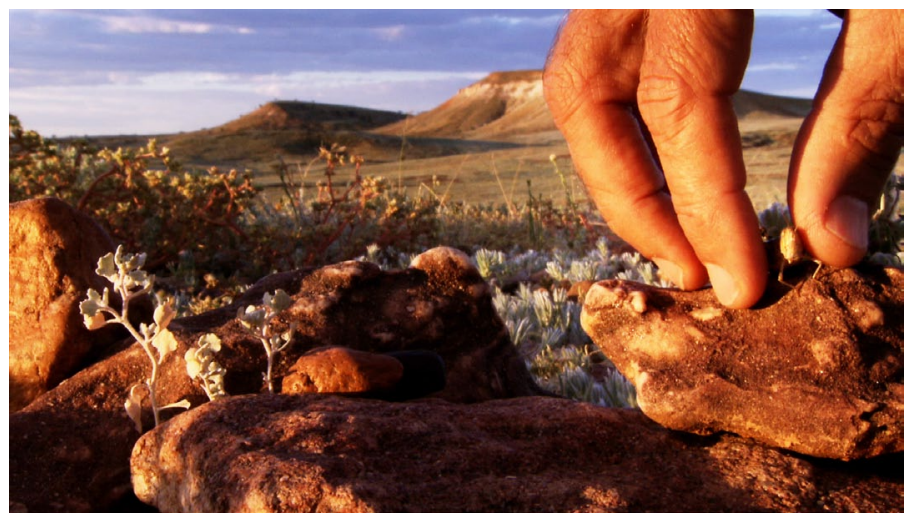

Figure 5 Still image from Memoirs of a Plague

\section{View End Sequence from Memoirs of a Plague ${ }^{36}$}

36 View associated media files via the ANU E Press website at http://epress.anu.edu.au/titles/humanitiesresearch-journal-series/humanities-research-vol-xviii-no-1-2012 
While I had been able to pursue open-ended ideas in Memoirs of a Plagueand indeed the impossibility of tying the locust down to one kind of certainty or interpretation was central to the filmmaking process-I found that the locust story is not so easily questioned when it comes to making a version for a television audience. As David MacDougall once pointed out in a conversation with Lucien Castaing-Taylor and Ilisa Barbash:

It is often difficult for people who express themselves through words to accept a form of communication that works so much through suggestion, implication, reference, ambiguity and comparison without conclusion. It can be frustrating for them. And there's the tendency to try and push it in a direction of being more definitive. Therefore there's always a demand for further contextualisation, for narration. ${ }^{37}$

MacDougall was referring to collaborations between filmmakers and anthropologists but the same dilemma occurred in my relationship with a major distribution network.

In a television documentary of the sort that I was constructing, any information is often framed by the notion that what the audience is told is something unique. New knowledge appears miraculously from 'science'. This knowledge is often withheld for dramaturgical purposes and then revealed as a startling new fact to the audience. It is explained through words, not images, in much the same way as many scientific texts work. It is assumed that for learning to take place in the viewer, they must be told facts. Deploying adjectives freely throughout the narration often propels sequences in such films. The narration is generally delivered breathlessly in a state of hyper-awareness and certainty. Time constraints faced by protagonists and a sense of jeopardy, explained by the voice-over, often provide the dramatic structure of this form of film. ${ }^{38}$ The spoken word sets up and structures the film by introducing and explaining the meaning and flow of all images and sequences. This can have the effect of rendering images meaningless unless there is an accompanying voice-over, while the words often advance independently of the images, with the same logic as expository written text. This interplay of image and voice is easy enough to test by turning down the sound on the television and seeing what sense can be made of the image flow, and then listening to the narration without watching the screen.

Andreas Ackermann has noted how the viewing and interpretation of an ethnographic film may transcend the intentions of the filmmaker, with the form of the film inviting viewers to imagine odours, taste food and listen to

37 Barbash, I. and Taylor, L. 1997, Cross-Cultural Filmmaking, University of California Press, Berkeley, p. 75.

38 Examples are numerous. In the locust sub-genre, they include cable TV documentaries such as Animal Planet's Swarm Chasers (2009) and National Geographic's Perfect Swarm (2005). 
sounds in a way that creates an experience that savours the world of the other. ${ }^{39}$ The viewers of television content are generally not allowed this opportunity because of the hegemony of words. Bresson had considered such a filmic form and concluded that by giving 'preponderance' to words, their sound can negate or even 'kill' an appreciation of the image. ${ }^{40} \mathrm{He}$ was well aware that words have the capacity to negate the mimetic affect that an image can create.

Content for television is a curated piece of media that is commissioned to follow a particular form or provide a consistent institutional voice. ${ }^{41}$ It will then fit comfortably in a predetermined slot in a television schedule or multimedia platform. Content can be designed, manufactured, packaged and sold to a mass market. This definition of content draws on my personal experience in pitching my locust film idea to the television commissioning editors at the Australian International Documentary Conference in Adelaide in 2009. Television commissioning editors commonly describe themselves as 'content seekers' at such events. Gary Kildea succinctly identified this form that they were seeking: he simply called them 'about' films. ${ }^{42}$ A film with locusts as 'content' was always going to mean the intervention of some form of exposition explaining the dramatic premise of their often-told story. In this form of film there is an implicit need to control what the film is 'about' for the audience so its content can be sold in a marketplace. To me, the imposition of a controlling narrative felt ironically similar to our need to control the locust itself. Dai Vaughan has noted that, in a sense, filming and the act of framing an image are always 'about' something, ${ }^{43}$ whereas the reality of life and the effervescent world around us, including locusts, are not 'about' anything. It is only when we peer at it through a recording device - the camera or the prism of own memories and beliefs - that our desire to impose a story is exposed.

\section{Conclusion}

The approach of ethnographic filmmaking significantly shaped my inquiry into locusts, enabling me to roam around our relationship with these creatures and their images, without feeling the need to impose a predetermined narrative structure on my investigation. I was led by my background research, my relationship with my subjects, an understanding of their motivations and the

\footnotetext{
39 Ackermann, A. 2011, Sensory patterns of culture: on researching social aesthetics, The 2011 Humanities Research Centre Seminar Series, 20 September, Research School of Humanities, The Australian National University, Canberra.

40 Bresson, Notes on the Cinematographer.

41 Fitzsimons, T., Laughren, P. and Williamson, D. 2011, Australian Documentary: History, practices and genres, Cambridge University Press, Cambridge.

42 Kildea, G. 2011, Personal communication.

43 Vaughan, D. 1999, For Documentary: Twelve essays, University of California Press, Berkeley, p. 21.
} 
use of a camera to observe their actions as social and cultural phenomena. The fact that locusts had an established narrative form in natural history films, and an established place in our imaginations, allowed me to present the subject in unexpected ways. I was also able to engage with this world by allowing the subject to become a source of wonder, rather than merely a source of information.

What I learnt from re-versioning the film for television was that it is not so easy to change the way people find meaning and consider things they believe they already know. As MacDougall has observed, there is an inner fear created by the act of looking, for, in looking, we may see 'the skull beneath the skin, the horror' ${ }^{44}$ We may be forced to acknowledge that we cannot control or contain all meanings that a film presents to an inquiring and critical gaze.

The use of voice-over narration is one of the primary forms in television documentary. I found that this tends to lock down meaning, rather than leaving the process of meaning-making open to the viewer's own encounter with material put before them. While Memoirs of a Plague utilised voice-over as an integral element of the film, this aimed at establishing disquiet, uncertainty and openness as the underlying sensibilities of the film. Such an approach runs directly counter to the ethos of the television documentary form. By the imposition of an explanatory voice-over, the viewer is excluded from a more open association with the images and sequences. This has a tendency to eviscerate any meaning that a sequence of images may potentially create for an audience, as the words impose and control the narrative. The image, and its role in the narrative of the film, is subordinated under their weight.

Memoirs of a Plague contemplates our need for certainty and control over nature. In Creatures of the Flood that need was played out in the demand to supply controlled and marketable content for television. The two films have different lives. One screens at film festivals; ${ }^{45}$ the other waits to be slotted into the program schedules of cable television channels around the world. One is an attempt to represent a series of open-ended ideas and the other is designed for its content. Memoirs of a Plague is very partial and propositional. Creatures of the Flood offers completeness and certainty. Memoirs of a Plague sets out to savour our relationship with the natural world; the other sets out to contain the frame of both questions and answers.

But although they are very different films they are forever linked, in my mind at least, in a way not dissimilar to the locust's capacity to exist in two forms.

\footnotetext{
44 MacDougall, The Corporeal Image, p. 8.

45 In 2010 Memoirs of a Plague screened at IDFA (Amsterdam), and in 2011 at the Margaret Mead Film Festival (New York), Hot Docs (Toronto), iDocs (Beijing), Mostra de Ciencia e Cinema (the International Science Film Festival, Coruña, Galicia, Spain), Canberra International Film Festival (Canberra) and Antenna Doc Fest (Sydney).
} 
Melville of course had something to say on the ambiguities of our relationship with beasts: ' $\mathrm{O}$ ' Nature, and $\mathrm{O}$ ' soul of man! how far beyond all utterance are your linked analogies.' ${ }^{46}$ 
